\title{
Population dynamics and reproductive biology of Barilius bendelisis (Cyprinidae: Cypriniformes) from river Gaula, Central Indian Himalaya
}

\author{
Neha Saxena ${ }^{1}$, Rabindar Singh Patiyal ${ }^{2}$, Kiran Dube*1 \& Virendra K. Tiwari ${ }^{1}$ \\ 1. Central Institute of Fisheries Education, Versova, Mumbai 400061; nehapnr@gmail.com, kirandr@cife.edu.in, \\ vktiwari@cife.edu.in \\ 2. Directorate of Coldwater Fisheries Research, Bhimtal 263136; rspatiyal1@gmail.com \\ * Correspondence
}

Received 19-VIII-2015. Corrected 11-III-2016. Accepted 13-IV-2016.

\begin{abstract}
The Indian hill trout cyprinid, Barilius bendelisis is a member of family Cyprinidae that dwells in shallow, cold, and clear water. In this study, growth parameters and reproductive biology of Indian hill trout, Barilius bendelisis from river Gaula, Central Himalaya region, India, were studied. The length-frequency data were grouped sex wise and were analyzed to determine the growth and mortality parameters using the computer software programme, FAO-ICLARM Stock Assessment Tool (FISAT II). Altogether, 501 individuals were collected from river Gaula (November 2013-October 2014) and were preserved in formalin for further analysis. The results showed that the female outnumbered the male population. The minimum GSI of females was observed in the month of October $(4.93 \pm 0.26)$ and for males in the month of June and July $(0.093 \pm 0.12)$, whereas, the maximum value was in the month of April for both females (13.47 \pm 0.52$)$ and males $(1.21 \pm 0.12)$. Fluctuation in GSI values had a bimodal pattern showing two peaks during March-May and August-September in both the sexes, indicating the common spawning period of fish. The slope of regression showed the negative allometric growth for both males and females ( $b=2.65$ for male and $b=2.5$ for female). A significant relationship between length and weight was observed in the present study $(\mathrm{p}<0.05)$. The ELEFAN-I estimated L $\infty$ and $\mathrm{K}$ of the von Bertalanffy growth factor for males $(17.33 \mathrm{~cm}$ and 0.310 per year), females $(17.33 \mathrm{~cm}$ and 0.3 per year) and pooled sexes $(17.33 \mathrm{~cm}$ and 0.240 per year). The results indicated that Barilius bendelisis is a small sized fish having negative allometric growth that spawns twice a year. Thus, the present study on biological traits represents the baseline information for effective production, conservation and restoration planning. Rev. Biol. Trop. 64 (3): 1287-1295. Epub 2016 September 01.
\end{abstract}

Key words: Barilius bendelisis, sex ratio, gonadosomatic index, river Gaula, India.

The Indian hill trout cyprinid, Barilius bendelisis (Hamilton) is a member of family Cyprinidae, subfamily Danioninae, dwells in shallow, cold and clear water (Gurung et al., 2005). It is characterized by the pointed head, compressed body, blue/black vertical bands on the lateral side of body and origin of dorsal fin inserted behind the mid of the body (Talwar \& Jhingran, 1991). This fish is an upland water fish, found in several countries of Southeast Asia such as India, Bangladesh, Nepal (Talwar \& Jhingran, 1991), Myanmar, Pakistan, Thailand and Srilanka (Eschmeyer \& Fricke, 2011). In India, this species is commonly distributed in Ganga and Brahmaputra drainages along the Himalayan foothills. Barilius bendelisis plays a considerable role in the capture fishery of the Himalayan parts of Arunachal Pradesh, inhabiting in lentic and lotic water bodies where other carps cannot be raised successfully (Sahoo, Saikia, \& Das, 2009).

Growth parameters are crucial for sustainable use and exploitation of aquatic macrofauna and their management (Yakub, 2010). Therefore, understanding the population dynamics of species in a particular condition, spawning season, growth, mortality, among others are pre-requisite for identifying the proper 
management techniques for the wild population (Rahman \& Hafzath, 2012).

$B$. bendelisis is a popular ornamental species among aquarists as well as a highly known for its food value among Himalayan population; recently it achieved a market price of Rs 160-200 per kg (US \$ 2.43-3.04) (Sharma, Akhtar, Pandey, Singh, \& Singh, 2015). As per IUCN red list $B$. bendelisis has been categorized as least concern (Vishwanath, 2010); however, however, its population has been gradually declining in natural water bodies in the recent past (Sah, Barat, Pande, Sati, \& Goel, 2011). Therefore, it is important to collect all the pre-requisite information on the growth and reproduction of this species as a tool for stock assessment, in order to meet the need of sustainable management of its fisheries, and to reduce the pressure on natural resources. Although the reproductive biology and length-weight analysis of $B$. bendelisis has been described by few authors (Dobriyal \& Singh, 1987; Gairola, Singh, Malhotra, Nanda, \& Ghildiyal, 1990; Grower, 1971; Mir, Patiyal, \& Sharma, 2015) but unfortunately, no studies on population dynamics have been reported for this species from river Gaula, Central Himalayans region, India. Therefore, the present investigation was taken up to assess the population dynamics and the reproductive biology of $B$. bendelisis in the river Gaula, Central Himalayans region, India.

\section{MATERIAL AND METHODS}

Study area: In total, 501 specimens of B. bendelisis (Total length, 6.25-17.20 cm) were collected based on external marking (vertical band) on the body from rivers Gaula (2917'25” N - 79³7'43” E), Kumaon region of Central Indian Himalayas at 595 MSL. Sampling was carried out on the monthly basis from November 2013 to October 2014. The weight of the fish was recorded with a precision balance nearest $0.01 \mathrm{~g}$. The total length of each fish was taken using digital caliper (Mitutoyo). After measuring length and weight of fish, these were dissected to determine the sex, and collect, weight and preserve gonads in Bouin's for further analysis.

The water quality parameters of river Gaula were recorded and found in optimum range throughout the study (water temperature, 8.48-25.2 ${ }^{\circ} \mathrm{C}$; $\mathrm{pH}, 7.8-9.1$; dissolved oxygen, 7.9-12.2 ppm; total dissolved solids, 32-114 ppm; alkalinity, 60-75 ppm; phosphate, 0.00-0.07 ppm; nitrite, 0.00-0.03; nitrate, 0.01-2.46 ppm and ammonia, 0.00-0.03 ppm).

Length weight relationship: The lengthweight relationship was analyzed following Le Cren (1951) by the formula: $\log W=\log$ $\mathrm{a}+\mathrm{b} \log \mathrm{L}$, where, $\mathrm{W}$ is the total weight of fish (gram); L is the total length of fish (cm); coefficient $\mathrm{a}$ is the intercept at Y-axis and regression coefficient $b$ is an exponent indicating the growth pattern of fish.

The length-weight relationship was estimated for males and females separately by transforming the values into logarithms values and fitting a straight line by least square method. The regression coefficient for males and females were compared by ANCOVA. Additionally, coefficient of determination $\left(\mathrm{R}^{2}\right)$ was estimated. The Fulton's condition factor $(\mathrm{K})$ for male, female has been calculated using the formula given by Ricker (1975) as Condition Factor $=($ Weight of fish $) /$ (Length of fish) $)^{3 *} 100$

The relative condition factor $(\mathrm{Kn})$ (Le Cren, 1951) was calculated separately for both the sexes using the formula $\mathrm{Kn}=\mathrm{W} / \mathrm{W}^{\wedge}$, where, $\mathrm{W}$ is observed weight and $\mathrm{W}^{\wedge}$ is calculated weight.

Population dynamics: The length-frequency data were grouped sex wise and were analyzed to determine the growth and mortality parameter using the computer software programme, FAO-ICLARM Stock Assessment Tool (FISAT II) (Gayanilo, Pauly, \& Sparre, 2005).

The Powell Wetherell Plot as modified by Pauly (1986) was adopted to obtain the initial asymptotic length $(\mathrm{L} \infty)$ and $\mathrm{Z} / \mathrm{K}$. Further, growth was investigated in terms of Asymptotic 
length $(\mathrm{L} \infty)$ and growth coefficient $(\mathrm{K})$ of the Von Bertalanffy Growth formula (VBGF) were estimated using ELEFAN I (Pauly \& David, 1981). Length converted catch data was used to compute the mortality (Z). Estimated L $\infty$ and $\mathrm{K}$ were used to calculate the growth performance index ( $\phi$ ') using formula (Pauly \& Munro, 1984): $\phi^{\prime}=2 \log 10 \operatorname{L} \infty+\log 10 \mathrm{~K}$.

Reproductive biology: The sex ratio was analyzed month wise during the experimental period. Chi-square formula (Snedecor \& Cochran, 1967) was used to test the expected 1:1 ratio deviation between males and females by applying the formula: $\mathrm{X}^{2}=\sum\left[(\mathrm{O}-\mathrm{E})^{2} / \mathrm{E}\right]$, where, $\mathrm{O}$ is observed number of males and females in each month and $\mathrm{E}$ is the expected number of males and females in each month.

Gonadosomatic index (GSI) was calculated month wise for both the sexes using formula (De Vlaming, Grossman, \& Chapman, 1982): GSI $=($ Gonads weight $) /($ Total weight of fish $)^{*} 100$.

\section{RESULTS}

Length-weight relation and condition factor: The length and weight of fish, regression equation of length-weight relationship, growth type, coefficient of determination $\left(\mathrm{R}^{2}\right)$, correlation coefficient (r), growth coefficient (b) and constant is given in table 1. The slope of regression shows the negative allometric growth for both the male and female $(b=2.65$ for male and $b=2.5$ for female). A significant relationship between length and weight was observed in the present study ( $\mathrm{p}$ $<0.05$ ). The results of the analysis of covariance (ANCOVA) revealed a significant difference in the regression coefficient of males and females $(\mathrm{p}<0.05)$.

The mean condition factor $(\mathrm{K})$ and relative condition factor $(\mathrm{Kn})$ for females, males and pooled sexes were 1.02, 0.97, 0.99 and $1.12,1.00,0.97$ respectively. Overall condition factor and relative condition factor of females (1.02 and 1.12 respectively) was better than males ( 0.97 and 1.00 respectively).

Population dynamics analysis: The estimated value of $\mathrm{L} \infty, \mathrm{Z} / \mathrm{K}$ for males $(19.68 \mathrm{~cm}$ and 5.074), females (22.38 cm and 6.841) and pooled sexes (and $23.93 \mathrm{~cm}$ and 8.176) of $B$. bendelisis as obtained from the Powell Wetherall Plot (Fig. 1). The growth performance index ( $\phi$ ') for males, females and pooled sexes were $1.96,1.95$ and 1.85 , respectively. The ELEFAN-I estimated $\mathrm{L} \infty$ and $\mathrm{K}$ of the von Bertalanffy growth factor for male $(17.33 \mathrm{~cm}$ and 0.310 per year), female $(17.33 \mathrm{~cm}$ and 0.3 per year) and pooled sexes $(17.33 \mathrm{~cm}$ and 0.240 per year) of Barilius bendelisis.

The length converted catch curve procedure generated an instantaneous total mortality (Z), Natural mortality (M), Fishing mortality (F) and exploitation rate (E) from the data points as $1.16,0.62,0.49$ and 0.42 per year, respectively.

Reproductive biology: The month wise sex distribution of male and female is given in table 2. Throughout the year there was a predominance of females except in the month of

TABLE 1

Descriptive statistics and Regression parameter of B. bendelisis from river Gaula of Central Indian Himalaya

\begin{tabular}{lcccccccccc}
\multicolumn{1}{c}{ Sex } & \multicolumn{1}{c}{ Descriptive statistics } & \multicolumn{1}{c}{ Regression Parameters } \\
& Average weight $(\mathrm{g})$ & Average total length $(\mathrm{cm})$ & $\mathrm{n}$ & $\mathrm{a}$ & $95 \%$ CL a & $\mathrm{b}$ & $95 \% \mathrm{CL} b$ & $\mathrm{R}^{2}$ & $\mathrm{r}$ & $\mathrm{S}$ \\
Female & $11.22 \pm 0.45(3.08-28.82)$ & $10.15 \pm 0.15(6.25-16.20)$ & 243 & -1.40 & -1.55 to -1.25 & 2.5 & 2.26 to 2.54 & 0.817 & 0.904 & $*$ \\
Male & $13.67 \pm 0.48(5.23-25.86)$ & $11.09 \pm 0.13(8.20-17.20)$ & 258 & -1.65 & -1.86 to -1.54 & 2.6 & 2.54 to 2.85 & 0.826 & 0.909 & $*$ \\
Pooled & $12.30 \pm 0.34(3.08-28.82)$ & $10.60 \pm 0.10(6.25-17.20)$ & 501 & -1.50 & -1.61 to -1.40 & 2.5 & 2.40 to 2.61 & 0.831 & 0.911 & $*$ \\
\hline
\end{tabular}

Note: $\mathrm{n}=$ number of samples, $\mathrm{a}=$ coefficient of regression intercept, $\mathrm{CL}=$ confidence level at $95 \%, \mathrm{~b}=$ coefficient of regression (slope), $\mathrm{R}^{2}=$ coefficient of determination, $\mathrm{r}=$ correlation coefficient, $\mathrm{S}=$ significant.

* Indicates significant at $95 \%$ confidence level $(\mathrm{p}<0.05)$. 

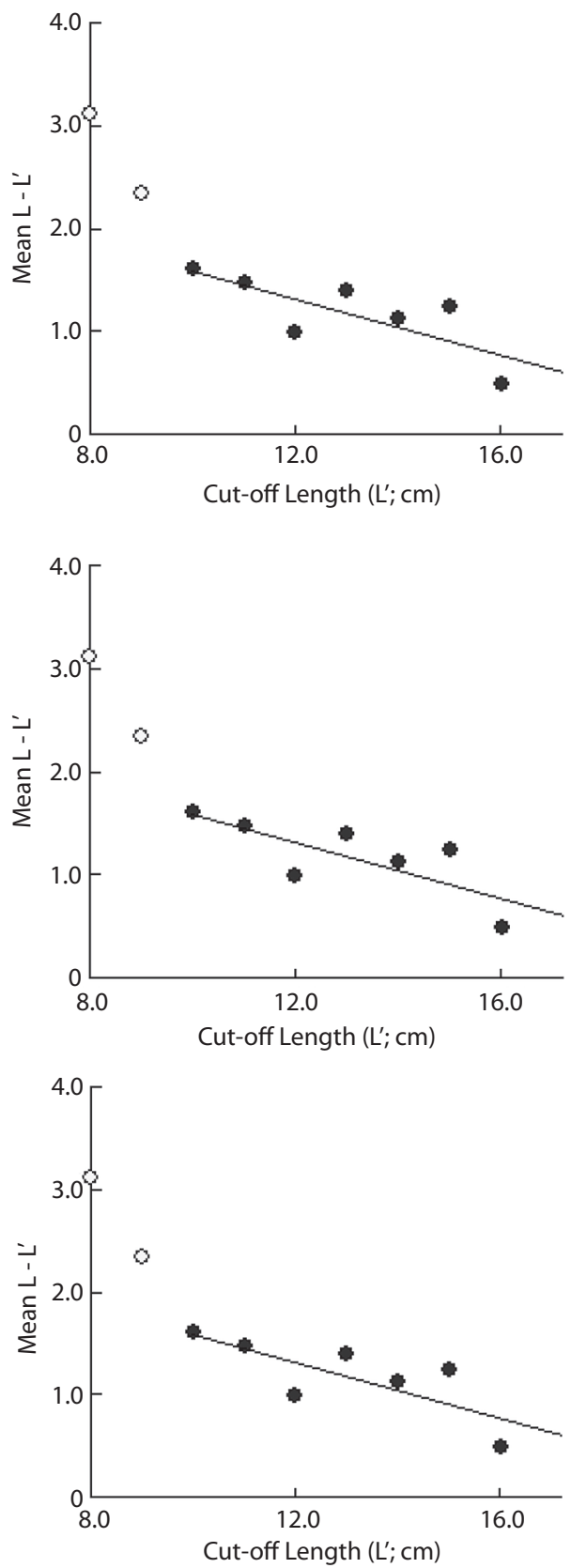

Fig. 1. Estimation of $\mathrm{L}_{\infty}$ and $\mathrm{Z} / \mathrm{K}$ using Powell Wetherall Plot for $B$. bendelisis in River Gaula of Central Indian Himalaya. A- Male $\left(\mathrm{L}_{\infty}=19.68 \mathrm{~cm}\right.$ and $\mathrm{Z} / \mathrm{K}=5.074$, correlation coefficient for the regression was $0.804, \mathrm{a}=$ 3.24 and $\mathrm{b}=-0.2)$; $\mathbf{B}$-Female $\left(\mathrm{L}_{\infty}=22.38 \mathrm{~cm}\right.$ and $\mathrm{Z} / \mathrm{K}=$ 6.841 , correlation coefficient for the regression was 0.645 , $\mathrm{a}=2.85$ and $\mathrm{b}=-0.12) ; \mathrm{C}$ - Pooled $\left(\mathrm{L}_{\infty}=23.93 \mathrm{~cm}\right.$ and $\mathrm{Z} / \mathrm{K}=8.176$, correlation coefficient for the regression was $0.704, a=2.61$ and $b=-0.11$ )
March, April, August and October, for which males outnumbered females. Chi-square test indicated the significant difference in the sex ratio during January and February. The minimum GSI of females was observed in the month of October $(4.93 \pm 0.26)$, and for males in the months of June and July $(0.093 \pm 0.12)$; whereas the maximum GSI value was observed for females in the month of April (13.47 \pm 0.52 ), and for males in the month of April $(1.21 \pm 0.12)$. However, GSI value during the months of March, April, May and September for females, and March, April, May, August and September for males, did not differ significantly $(\mathrm{p}<0.05)$ (Fig. 2). Fluctuation in GSI value showed a bimodal pattern showing two peaks during March to May and AugustSeptember in both sexes.

\section{DISCUSSION}

Information on population dynamics and biological aspects of Barilius bendelisis from the River Gaula, Kumaon region of Uttarakhand is deficient. However, several authors (Dobriyal \& Singh, 1987; Gairola, Singh, Malhotra, Nanda, \& Ghildiyal, 1990; Mir, Patiyal, \& Sharma, 2015) have done a brief study of the biological aspect from Garhwal region of Uttarakhand, India.

Length-weight relationship plays a significant role in fisheries sciences as it helps in estimating weight of fish from its length (Martin-Smith, 1996; Mir, Shabir, \& Mir, 2012), calculating growth, biomass, gonadal maturity, seasonal variation in growth and production of population (Le Cren, 1951; Pauly, 1983; Rahman \& Hafzath, 2012). The allometric coefficient (b) during the present study was found within the expected range of 2.5-3.5 (Carlander, 1969; Froese, 2006; Pauly \& Gayanilo, 1997), but it can fluctuate between 2.5 to 4 (Bagenal \& Tesch, 1978). In general, the regression coefficient $b$ for fish which exhibits isometric growth $(b=3)$ shall not differ significantly from 3 (Allen, 1938), and weight of fish should vary as the cube of length. As the value of $b$ deviates from 3 , then weight increase of 
TABLE 2

Monthly variation in sex ratio of $B$. bendelisis collected from river Gaula of Central Indian Himalaya

\begin{tabular}{|c|c|c|c|c|}
\hline Month & Percent male (M, \%) & Percent female $(\mathrm{F}, \%)$ & M:F & Significance \\
\hline November 2013 & 53.2 & 46.2 & $1: 2.3$ & Ns \\
\hline December 2013 & 53.8 & 46.2 & $1: 2.3$ & Ns \\
\hline January 2014 & 20.8 & 79.2 & $1: 3.8$ & $\mathrm{~S}$ \\
\hline February 2014 & 16.1 & 83.9 & $1: 5.2$ & $\mathrm{~S}$ \\
\hline March 2014 & 51.9 & 48.1 & $1: 0.9$ & Ns \\
\hline April 2014 & 57.7 & 42.3 & $1: 0.73$ & Ns \\
\hline May 2014 & 47.6 & 52.4 & $1: 1.1$ & Ns \\
\hline June 2014 & 50.0 & 50.0 & $1: 1$ & Ns \\
\hline July 2014 & 47.9 & 52.0 & $1: 1.1$ & Ns \\
\hline August 2014 & 53.8 & 46.2 & $1: 0.85$ & Ns \\
\hline September 2014 & 50.0 & 50.0 & $1: 1$ & Ns \\
\hline October 2014 & 58.3 & 41.7 & $1: 0.71$ & Ns \\
\hline Total & & & $1: 1.2$ & \\
\hline
\end{tabular}

Note: Ns $=$ non-significant $(\mathrm{p}>0.05) ; \mathrm{S}=$ significant $(\mathrm{p}<0.05)$.

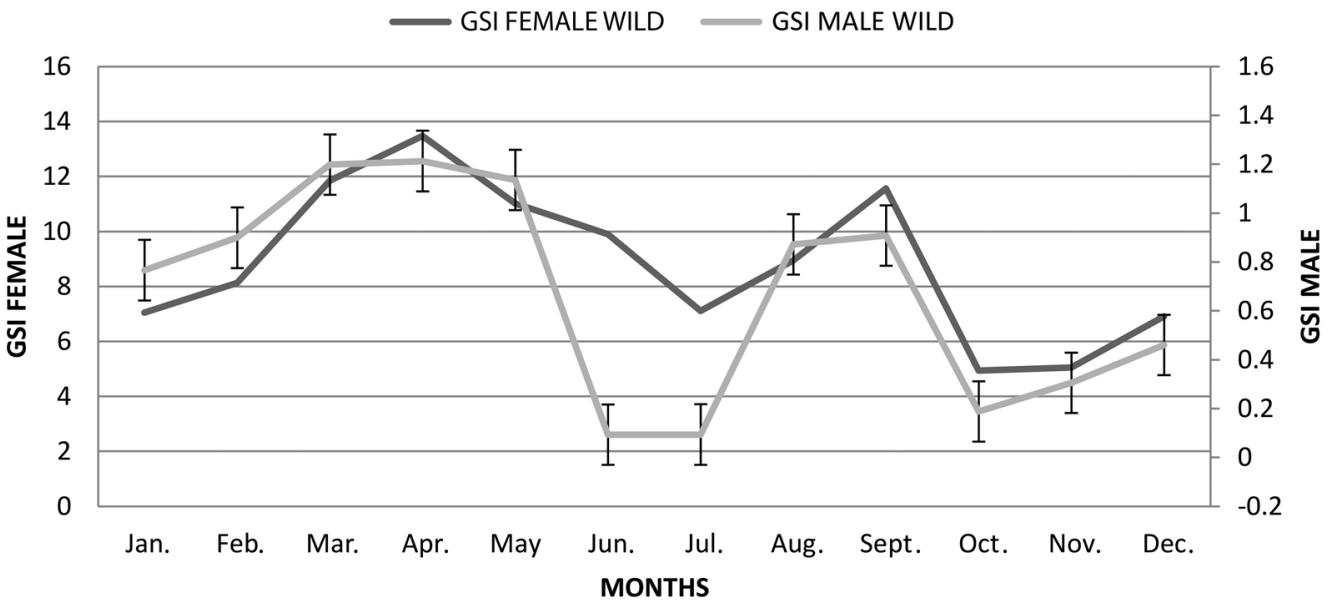

Fig. 2. Gonadosomatic Index (GSI) of male and female B. bendelisis collected from river Gaula of central Indian Himalaya.

fish exhibits allometric behavior. In case of Barilius bendelisis, negative allometric growth was observed $(b<3)$, which indicates that the weight of fish increased by the power less than 3 with unit increase in body total length showing deviation from the cube law. Such deviation from cube law is reported by several authors in variety of fishes such as Barilius bendelisis (Gairola, Singh, Malhotra, Nanda, \& Ghildiyal, 1990), major carps (Jhingran, 1952), Labeo calbasu (Rao \& Rao, 1972), Labeo fimbriatus
(Rao, 1974), Indian major carps (Mohan \& Sankaran, 1988) and Pangasius pangasius (Deepak, Sarkar, \& Negi 2002). Mir, Patiyal, \& Sharma (2015) reported growth regression coefficient less than 3 in Barilius bendelisis $(\mathrm{b}=$ $2.84)$ and Barilius vagra $(\mathrm{b}=2.97)$ from spring fed stream of Garhwal Himalayas. In case of Barilius bendelisis, the $\mathrm{b}$ value was more or less similar for both sexes, and was marginally higher in case of males, indicating that males were comparatively heavier than the females 
of the same length group. These changes may be due to various factors involved in growth of fish like availability of food and feeding (Le Cren, 1951), gonadal maturity (Frost, 1945), sex (Hile \& Jobes, 1942) between different population of species (Hile, 1936; Jhingran, 1968), season, habitat, stomach fullness and preservation techniques (Bagenal \& Tesch, 1978; Soomro, Baloch, Jafri, \& Suzuki, 2007). The results of this study coincided with the results of Gairola, Singh, Malhotra, Nanda, \& Ghildiyal (1990) in Barilius bendelisis from Garhwal Himalayas.

Condition factor $(\mathrm{K})$ of fish reflects the physiological condition of fish (fatness, maturity and gonadal development) and general welfare in relation to fish health (Shakir, Mirza, Khan, \& Abid, 2008; Rahman \& Hafzath, 2012). In the present study, the value of $K$ of Barilius bendelisis deviated from the recommended range of 2.90-4.80 for mature freshwater fishes (Bagenal \& Tesch, 1978). This deviation could be due to environmental factors such as water temperature, water fluctuation and conductivity (Dalu, Clegg, \& Nhiwatiwa, 2013).

Asymptotic length $(\mathrm{L} \infty)$ denoted the largest hypothetical size a fish species may attain throughout its life span in its ecological habitat and environment (Etim, Sankare, Brey, \& Arntz, 1998). Generally, growth parameters (growth coefficients, growth performance index) are species-specific in nature and their values are commonly similar within the taxa with narrow normal distribution (Etim, Brey, \& Arntz, 1996). Due to lack of data on population structure of Barilius bendelisis, the results of present study could not be compared with the other studies of Barilius bendelisis. Branstetter (1987) classify the growth of fish based on its $\mathrm{K}$ value as $0.05-0.10 / \mathrm{y}$ for slowly growing species, $0.10-0.20 / y$ for average growing species and $0.20-0.50 / y$ for rapidly growing species. So, based on this criterion, Barilius bendelisis falls under the rapidly growing species.

The sex ratio of Barilius bendelisis in the present study showed a deviation from $1: 1$, with the predominance of females $(1: 2)$.
Dobriyal \& Singh (1987) obtained similar results in Barilius bendelisis from Garhwal Himalaya, India. The unequal sex ratio in Barilus bendelisis population of river Gaula may be attributed to higher total mortality of male as reported in the present study. Del-Zarka \& El-Sedfy (1970) reported that physical activity and differences in natural and fishing mortality between the sexes are important factors that influence sex ratio (Del-Zarka \& El-Sedfy, 1970). Qasim (1966) also concluded that dominance of one sex in a population is linked to differences in growth rate of sexes as individuals with faster growth are exposed to low predation and subsequent loss from population, hence, this influences sex ratio. However, this can result from several physiological factors such as inter specific sex physiology, sex linked tolerance of species, and differential migration of species (Sarkar, Kumar, Dubey, Pandey, \& Lakra, 2012).

Gonado Somatic Index is a reliable indicator of gonadal maturity, as in general, the weight of the gonad increases with maturity. When fish spawns, there is a decrease in the weight of the gonad because of the release of gametes (De Vlaming, Grossman, \& Chapman, 1982). The changes in the magnitude of GSI in the present study revealed that the Barilius bendelisis spawns twice in a year during March to May, and in the month of September, which is similar as reported by Dobriyal \& Singh (1987). However, Grower (1971) has reported that Barilius bendelisis spawns during the month of November to December.

The present study revealed growth pattern, dynamics and reproductive biology of Barilius bendelisis in river Gaula of Central Himalaya region, India. The present investigation concluded that Barilius bendelisis is a small sized fish with comparatively good growth rate that spawns twice a year. However, mortality and exploitation rate of target species is quite high in River Gaula. Therefore, there is a need to reduce the fishing pressure by imposing several restrictions in fishing for getting the sustainable yield of fish from River Gaula. Hence, the present study will provide the baseline 
information on biological and population structure aspects of this species, and will be useful for its effective production, conservation and restoration plans.

\section{ACKNOWLEDGMENTS}

We sincerely, thank to W. S. Lakra, Director, Central Institute of Fisheries Education, Mumbai and A. K. Singh Director Directorate of Coldwater Fisheries Research for providing necessary facilities. Department of Science and Technology is greatly acknowledged for providing Inspire fellowship to Neha Saxena to carry out the research work.

The Indian hill trout cyprinid, Barilius bendelisis is a member of family Cyprinidae that dwells in shallow, cold, and clear water. In this study, growth parameters and reproductive biology of Indian hill trout, Barilius bendelisis from river Gaula, Central Himalaya region, India, were studied. The length-frequency data were grouped sex wise and were analyzed to determine the growth and mortality parameters using the computer software programme, FAO-ICLARM Stock Assessment Tool (FISAT II). Altogether, 501 individuals were collected from river Gaula (November 2013-October 2014) and were preserved in formalin for further analysis. The results showed that the female outnumbered the male population. The minimum GSI of females was observed in the month of October $(4.93 \pm 0.26)$ and for males in the month of June and July $(0.093 \pm 0.12)$, whereas, the maximum value was in the month of April for both females $(13.47 \pm 0.52)$ and males $(1.21 \pm 0.12)$. Fluctuation in GSI values had a bimodal pattern showing two peaks during March-May and August-September in both the sexes, indicating the common spawning period of fish. The slope of regression showed the negative allometric growth for both males and females $(b=2.65$ for male and $b=2.5$ for female). A significant relationship between length and weight was observed in the present study $(\mathrm{p}<0.05)$. The ELEFAN-I estimated L $\infty$ and $\mathrm{K}$ of the von Bertalanffy growth factor for males $(17.33 \mathrm{~cm}$ and 0.310 per year), females $(17.33 \mathrm{~cm}$ and 0.3 per year) and pooled sexes (17.33 $\mathrm{cm}$ and 0.240 per year). The results indicated that Barilius bendelisis is a small sized fish having negative allometric growth that spawns twice a year. Thus, the present study on biological traits represents the baseline information for effective production, conservation and restoration planning.

\section{RESUMEN}

Dinámica poblacional y biología reproductiva de Barilius bendelisis (Cyprinidae: Cypriniformes) en el río Gaula del Himalaya Central, India. Barilius bendelisis es un miembro de la familia Cyprinidae que habita en agua superficial, fría y clara. En esta investigación se estudiaron los parámetros de crecimiento y la biología reproductiva de Barilius bendelisism en el río Gaula, Himalaya Central, India. Los datos talla-frecuencia fueron agrupados por sexo, y analizados para determinar parámetros de crecimiento y mortalidad usando el programa de computador, FAO-ICLARM Stock Asseessment Toll (FISAT II). En total, 501 individuos fueron recolectados en el río Gaula (Noviembre 2013-Octubre 2014) y fueron preservados en formalina para futuros análisis. Los resultados mostraron que la población de hembras supera en número la población de machos. El GSI mínimo en hembras fue observado en octubre $(4.93 \pm 0.26)$ y en machos en Junio y Julio $(0.093 \pm 0.12)$, mientras, el valor máximo en abril para ambos, hembras $(13.47 \pm 0.52)$ y machos $(1.21 \pm 0.12)$. La fluctuación en los valores del GSI tenía un patrón bimodal mostrando dos picos durante Marzo-Macho y Agosto-Septiembre en ambos sexos, indicando el periodo de desove común del pez. La pendiente de regresión muestra crecimiento alométrico negativo tanto para machos como para hembras $(b=2.65$ para machos y $b=2.5$ para hembras). Se observó una significativa relación entre talla y peso en el presente estudio $(p<0.05)$. El ELEFAN-I estimó $\mathrm{L} \infty$ y $\mathrm{K}$ del factor de crecimiento von Bertalanffy para machos (17. $33 \mathrm{~cm}$ y 0.310 por año), hembras (17.33 cm y 0.3 por año) y sexos combinados $(17.33 \mathrm{~cm}$ y 0.240 por año). Los resultados indicaron que Barilius bendelisis es un pez de talla pequeña con un crecimiento alométrico negativo que desova dos veces al año. Además, el presente estudio de rasgos biológicos representa la información de base para la efectiva producción, conservación y planeamiento de la restauración.

Palabras clave: Barilius bendelisis, sex ratio, índice gonadosomático, río Gaula, India. 


\section{REFERENCES}

Allen, K. R. (1938). Some observations on the biology of the trout (Salmo trutta) in Windermere. Journal of Animal Ecology, 4, 264-273.

Bagenal, T. B., \& Tesch, F. W. (1978). Age and growth. In T. Begenal (Ed.), Methods for assessment of fish production in fresh waters (pp. 101-136). Oxford: Blackwell Science Publications.

Branstetter, S. (1987). Age and growth estimates for blacktip, Carcharhinus limbatus, and sipnner, Carcharhinu sbrevipinna, sharks from the northwestern Gulf Mexico. Copeia, 4, 946-974.

Carlander, K. D. (1969). Handbook of freshwater fishery biology (volume 1). Iowa: The Iowa State University Press, Ames.

Dalu, T., Clegg, B., \& Nhiwatiwa, T. (2013). Lengthweight relationships and condition factors of six fish species caught using gill nets in a tropical African reservoir, Zimbabwe. Transactions of the Royal Society of South Africa, 68, 75-79.

De Vlaming, V. L., Grossman, G., \& Chapman, F. (1982). On the use of the gonosomatic index. Comparative Biochemistry and Physiology, 73A, 31-39.

Deepak, P. K., Sarkar, U. K., \& Negi, R. S. (2002). Studies on certain biometric features of Pangasius pangasiusfrom the river Bhagirathi. In S. P. Singh, D. Kapoor, U. K. Sarka, \& V. S. Basheer (Eds.), Life history traits of freshwater fish population for its utilization in conservation. Lucknow, U.P, India: NBFGR-NATP Publication No.4. Abstract No. AA-8. NBFGR.

Del-Zarka, S. E., \& El-Sedfy, H. M. (1970). The biology and fishery of Mugilsaliens(Risso) in lake Quarium, VAR. Bulletin of the National Institute of Oceanography and Fisheries, 1, 3-26.

Dobriyal, A. K., \& Singh, H. R. (1987). The reproductive biology of hill stream minor carp Barilius bendelisis from Garhwal Himalaya India.Vestnik Ceskoslovenske Spolecnosti Zoologicke, 51, 1-10.

Eschmeyer, W. N., \& Fricke, R. (Eds.). (2011). Catalog of Fishes electronic version (29 March 2011). Retrieved from http://research.calacademy.org/ichthyology/ catalog/fishcatmain.asp.

Etim, L., Brey, T., \& Arntz, W. (1996). A seminal study of the dynamics of a Mudskiper (Periophthalmuspapilio) population in the cross river, Nigeria. Fisheries Research, 40, 295-307.

Etim, L., Sankare, Y., Brey, T., \& Arntz, W. (1998). The dynamics of unexploited population of Corbulatrigona (Bivalvia: Corbulidae) in a brakish-water lagoon, Cote d'lvoire. Archive of Fishery and Marine Research,46, 253-262.
Froese, R. (2006). Cube law, condition factor and weightlength relationships: history, meta analysis and recommendations. Journal of Applied Ichthyology, $22,241-253$.

Frost, W. E. (I945). The age and growth of eels (Anguilla anguilla) from the Windermere catchment area. Part 2. Journal of Animal Ecology, I4, I 06-24.

Gairola, D., Singh, O. M., Malhotra, S. K., Nanda, S., \& Ghildiyal, R. P. (1990). Parasities, ponderal index and length weight relationship of Barilius bendelisis (Ham.) and Puntiusticto (Ham.). Indian Journal of Fisheries, 37, 361-365.

Gayanilo, F. C., Pauly, D., \& Sparre, P. (2005). FISAT User's Guide. FISAT II. Retrieved from http//www. fao.org/fi/statist/fisoft/fisat/downloads.

Grower, S. P. (1971). Some biological notes on Barilius bendelisis (Hamilton). Indian Journal of Fisheries, $18,182-183$.

Gurung, T. B., Wagle, S. K., Bista, J. D., Joshi, P. L., Batajoo, R., Adhikari, P., \& Rai, A. K. (2005). Participatory fisheries management for livelihood improvement of fishers in Phewa Lake, Pokhara, Nepal. Himalayan Journal of Sciences, 3, 47-52.

Hile, R. (1936). Age and growth of the cisco Leucichthys artedi (Le Sueur), in the lakes of the north-eastern highlands, Wisconsin. Bulletin of the United States Bureau of Fisheries, 48, 211-317.

Hile, R., \& Jobes, F. W. (1942). Age and growth of the yellow perch, Perca flavescens (Mitchill), in the Wisconsin waters of Green Bay and northern Lake Michigan. Papers of the Michigan Academy of Science, 27, 241-66.

Jhingran, V. G. (1952). General length-weight relationship of three major carps in India. Proceedings of National Institute of Science India, 17, 499-460.

Jhingran, A. G. (1968). The length-weight relationship and $\mathrm{K}$ factor of Gudusia chapra (Ham) from the Ganga river system. Proceedings of the National Academy of Sciences India, 249-263.

Kurup, B. M., Radhakrishnan, K. V., \& Manojkumar, T. G. (2004). Biodiversity status of fishes inhabiting rivers of Kerala (SouthIndia) with special reference to endemism, threats and conservation measures. In R. L Welcome, \& T. Peter (Eds.), Proceeding of the second international symposium on the management of large rivers for fisheries (pp.163-182). Phnom Penh, Kingdom of Cambodia: Mekong River Commission (MRC) and Food and Agricultural Organization (FAO).

Le Cren, E. D. (1951). The length-weight relationship and seasonal cycle in the gonad weight and condition in the perch (Percafluviatilis). Journal of Animal Ecology, 20, 201-219. 
Martin-Smith, K. M. (1996). Length/weight relationships of fishes in a diverse tropical fresh-water community, Sabah, Malaysia. Journal of Fish Biology, 49, 731-734.

Mir, J. I., Patiyal, R. S., \& Sharma, N. K. (2015). Analysis of length-weight relationship of sympatric hill stream teleosts Barilius bendelisis (Hamilton, 1807) and Barilius vagra (Hamilton, 1822) from Garhwal Himalaya, India. Journal of Applied Ichthyology, doi: 10.1111/jai.12688

Mir, J. R., Shabir, R., \& Mir, F. A. (2012). Length-Weight Relationship and Condition Factor of Schizopyge curvifrons (Heckel, 1838) from River Jhelum, Kashmir, India. World Journal of Fish and Marine Sciences, 4, 325-329.

Mohan, M. V., \& Sankaran, T. M. (1988). Length-weight relationship of Indian major carps with improvement in expressing exponential formula. Journal of Aquaculture in the Tropics, 3, 43-46.

Pauly, D. (1983). Some simple methods for the assessment of tropical fish stocks. FAO Fisheries Technical Paper, 234, 1-52.

Pauly, D. (1986). On improving operation and use of the ELEFAN programs. Part II. Improving the estimation of Lo ICLARM. Fishbyte, 4, 18-20.

Pauly, D., \& David, N. (1981). ELEFAN I: a basic program for the objective extraction of growth parameters from length-frequencies data. Meeresforsch, 28, 205-11.

Pauly, D., \& Gayanilo, Jr. F. C. (1997). ABee: An alternative approach to estimating the parameters of a length-weight relationship from length-frequency samples and their bulk weights. Manila, Philippines: ICLARM.

Qasim, S. Z. (1966). Sex-ratio in fish populations as a function of sexual difference in growth rate. Current Science, 35, 140-142.

Rahman, M. M., \& Hafzath, A. (2012). Condition, lengthweight relationship, sex ratio and gonasosomatic index of Indian Mackeral (Rastrelliger kanagurta) captured from Kuantan coastal water. Journal of Biological Sciences, 12, 426-432.

Rao, G. R. (1974). Observation on the age and growth, maturity and fecundity of Labeo fimbriatus (Bloch) of the river Godavari. Indian Journal of Fisheries, $21,427-445$.

Rao, G. R., \& Rao, L. H. (1972). On the biology of Labeo calbasu (Ham.-Buch.) from river Godavari. Journal of Inland Fisheries Society of India, 4, 74-86.
Ricker, W. E. (1975). Computation and interpretation of biological statistics of populations. Journal of the Fisheries Research Board of Canada, 191, 382.

Sah, S., Barat, A., Pande, V., Sati, J., \& Goel, C. (2011). Population Structure of Indian Indian Hill trout (Barilius bendelisis) inferred from variation in Mitochondrial DNA sequences. Advances in Biological Research, 5, 93-98.

Sahoo, P. K., Saikia, S. K., \& Das, D. N. (2009). Natural food resources and niche breadth of Barilius bendelisis (Hamilton) (Pisces, Cyprinidae) in river Dikrong, an upland riverine ecosystem in India. Pan-American Journal of Aquatic Sciences, 4, 12-16.

Shakir, H. A., Mirza, M. R., Khan, A. M., \& Abid, M. (2008). Weight length and condition factor relationship of Sperata sarwari (Singhari) from Mangla Lake, Pakistan. Journal of Animal and Plant Science, 18, 158-161.

Sarkar, U. K., Kumar, R. S., Dubey, V. K., Pandey, A., \& Lakra, W. S. (2012). Population structure and reproductive biology of a freshwater fish Labeo boggut (Skyes, 1839), from two perennial rivers of Yamuna basin. Journal of Applied Ichthyology, 28,107-115.

Sharma, N. K., Akhtar, M. S., Pandey, N., Singh, R., \& Singh, A. K. (2015). Seasonal variation in thermal tolerance, oxygen consumption, antioxidative enzymes and non-specific immune indices of Indian hill trout, Barilius bendelisis (Hamilton, 1807) from central Himalaya, India. Journal of Thermal Biology, $52,166-176$

Snedecor, G. W., \& Cochran, W. C. (1967). Statistical Methods. Calcutta, India: Oxford and IBH Publishing House.

Soomro, A. N., Baloch, W. A., Jafri, S. I. H., \& Suzuki, H. (2007). Studies on length-weight and lengthlength relationships of a catfish Eutropiichthyes vacha Hamilton (Schilbeidae: Siluriformes) from Indus river, Sindh, Pakistan. Caspian Journal of Environmental Sciences, 5, 143-145.

Talwar, P. K., \& Jhingran, A. G. (1991). Inland fishes of India and adjacent countries. USA: CRC Press.

Vishwanath, W. (2010). Barilius bendelisis. The IUCN Red List of Threatened Species 2010: e.T166594A6243552. Retrieved from http:// dx.doi.org/10.2305/IUCN.UK.2010-4.RLTS. T166594A6243552.en.

Yakub, A. S. (2010). Population growth of three freshwater prawns (Macrobrachium spp.) in Lower Ogun River, Southwest Nigeria. International Journal of Biological and Chemical Sciences, 4, 797-802. 
